\title{
Drawing perseveration in the behavioral variant of frontotemporal dementia
}

\section{Figure Drawing perseveration}
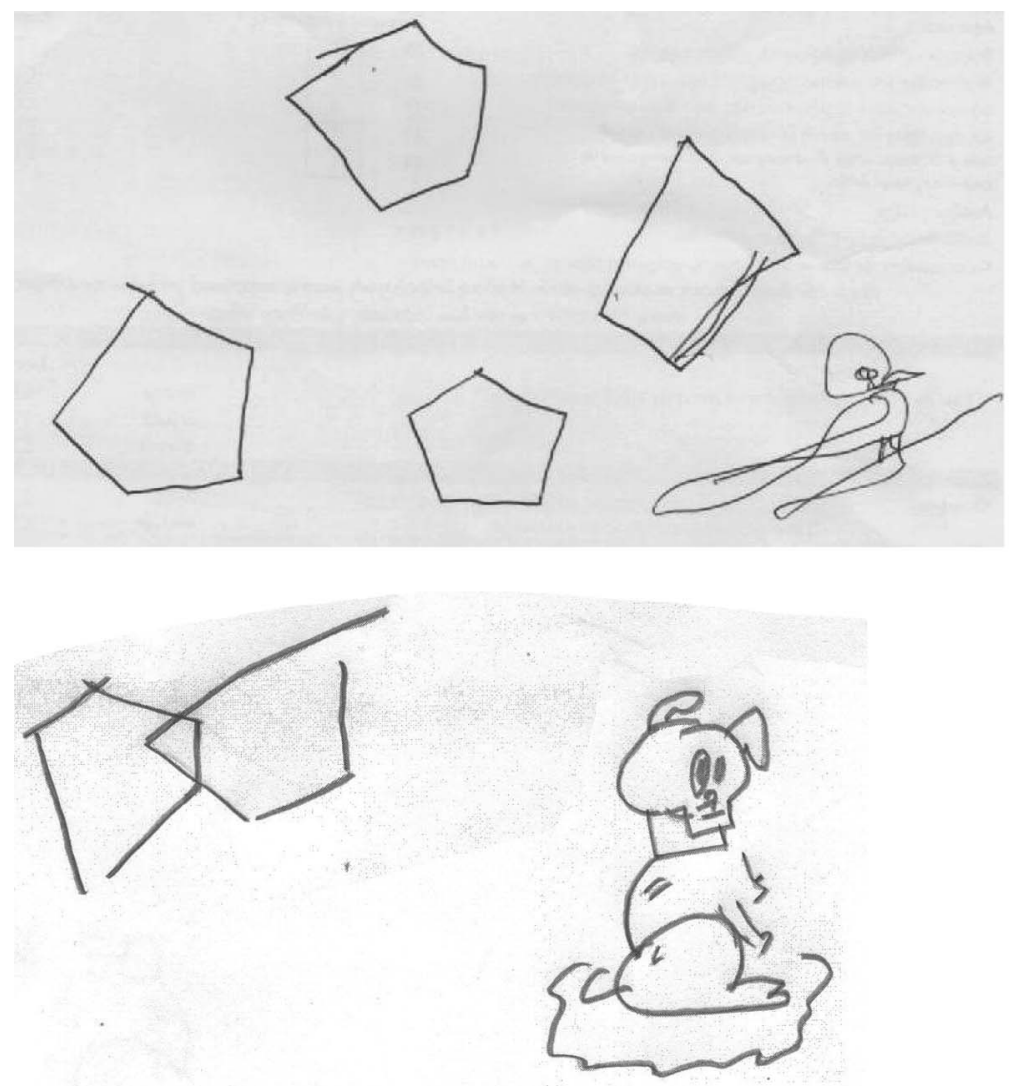

The first patient drew a pigeon and the second drew a dog after they were asked to copy the pentagons.

The behavioral variant of frontotemporal dementia (bvFTD) represents a distinct clinical FTD subtype, dominated by progressive deterioration in cognition, personality, and social conduct. Perseverative behavior is a core clinical feature in the proposed diagnostic criteria. ${ }^{1}$ Two patients with bvFTD exhibited a peculiar form of perseveration, which we named drawing perseveration. During neuropsychometric testing, especially after copying pentagons, they both spontaneously drew animals: a pigeon or a dog (figure). They both used to draw these animals during childhood, but not during adulthood, in contrast to the emergence of artistic talent that can occur in FTD. ${ }^{2}$

Panagiotis Ioannidis, MD, PhD, Eleni Konstantinopoulou, MSc, Dimitris Karacostas, MD, PhD

From the 2nd Department of Neurology, AHEPA University Hospital, Thessaloniki, Greece.

Author contributions: Dr. Ioannidis: study concept and design. E. Konstantinopoulou: acquisition of data. Dr. Karacostas: study supervision. Study funding: No targeted funding reported.

Disclosure: The authors report no disclosures relevant to the manuscript. Go to Neurology.org for full disclosures.

Correspondence to Dr. Ioannidis: ispanagi@auth.gr

1. Rascovsky K, Hodges RJ, Knopman D, et al. Sensitivity of the revised diagnostic criteria for the behavioural variant of frontotemporal dementia. Brain 2011;134:2456-2477.

2. Miller BL, Cummings J, Mishkin F, et al. The emergence of artistic talent in frontotemporal dementia. Neurology 1998;51:978-982. 


\section{Neurology}

\section{Drawing perseveration in the behavioral variant of frontotemporal dementia Panagiotis Ioannidis, Eleni Konstantinopoulou and Dimitris Karacostas \\ Neurology 2015;84;101 \\ DOI 10.1212/WNL.0000000000001108}

\section{This information is current as of December 29, 2014}

Updated Information \& Services

References

Subspecialty Collections

Permissions \& Licensing

Reprints including high resolution figures, can be found at: http://n.neurology.org/content/84/1/101.full

This article cites 2 articles, 1 of which you can access for free at: http://n.neurology.org/content/84/1/101.full\#ref-list-1

This article, along with others on similar topics, appears in the following collection(s):

All Cognitive Disorders/Dementia

http://n.neurology.org/cgi/collection/all_cognitive_disorders_dementia Corticobasal degeneration

http://n.neurology.org/cgi/collection/corticobasal_degeneration

Dementia aphasia

http://n.neurology.org/cgi/collection/dementia_aphasia

Frontotemporal dementia

http://n.neurology.org/cgi/collection/frontotemporal_dementia

Information about reproducing this article in parts (figures,tables) or in its entirety can be found online at:

http://www.neurology.org/about/about_the_journal\#permissions

Information about ordering reprints can be found online:

http://n.neurology.org/subscribers/advertise

Neurology ${ }^{\circledR}$ is the official journal of the American Academy of Neurology. Published continuously since 1951 , it is now a weekly with 48 issues per year. Copyright @ 2014 American Academy of Neurology. All rights reserved. Print ISSN: 0028-3878. Online ISSN: 1526-632X.

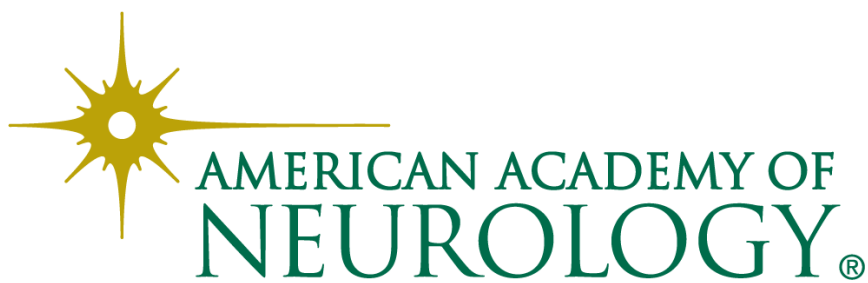

